\title{
Aspects of The Evolution of Enterprises in Member States of The European Union
}

\author{
By Petrică Sorin Angheluță ${ }^{1}$, Dumitru Alexandru Bodislav ${ }^{1}$, \\ Maria Loredana Popescu ${ }^{1}$, Florina Bran ${ }^{1}$
}

\begin{abstract}
A solid industrial base positively influences society as a whole. Business development is favored by the degree to which companies are active in the market. The article presents an analysis of employment in companies active in the Member States of the European Union. The evolution of the establishment of active enterprises according to their branches of activity is also addressed. Openness to local markets can lead to successful business activities. Cooperation between different companies can also be facilitated by new technologies. From the point of view of mobility, employment in foreign affiliates of domestic enterprises is another subdomain analyzed in the article. The way in which companies approach the field of expenditure can influence their activity. Thus, by increasing technological capacities and promoting innovation, technological development measures lead to the development of enterprises. The article presents an analysis of the way in which expenditure is shared at the level of enterprises in the Member States of the European Union.
\end{abstract}

Keywords: enterprises, sustainable development, European Union

\section{Introduction}

One of the issues of the next period is how Europe's industry will make the transition to climate neutrality (Radulescu et al., 2020). The European Union's industrial policy will need to be based on innovation in order to achieve accelerated economic growth (Angheluta et al., 2019). Increasing resource consumption should not implicitly lead to economic growth (EC, 2020). Periods of crisis can have different influences on economies. Thus, a higher level of education contributes to the easier overcoming of such periods (Curry, 2019). For start-ups, the transition to digital and green economies can be facilitated by financial support (Bran et al., 2018). A successful transition can be achieved with the help of a skilled workforce (Costache et al., 2015). The way companies operate is influenced by the digitization process (Androniceanu et al., 2017). Thus, it is considered that those companies that have made the transition to new business models based on digital technologies are more advantaged (Burlacu et al., 2019). Measures to accelerate the economic recovery, due to periods of crisis, can be based on resilient supply chains. For the workforce, in such situations, it is necessary to apply new standards and regulations (Ionita et al., 2009). Companies can thrive if they have a skilled workforce and quality jobs (EC, 2021).

Over the years, the workforce in companies is influenced by the way employees view their own careers (Sarbu et al., 2021). The solutions they adopt also have effects on the 
companies they belong to. Career transitions are considered to be due to both technical progress and globalization (Sullivan \& Ariss, 2021).

Situations may arise in which an expansion of production capacity and, implicitly, an increase in labor force is a consequence of the existence of competing companies for which production costs are lower (Grodzicki \& Skrzypek, 2020).

\section{Literature Review}

The service-based economy, as well as the possibility of conducting digital business transactions, has led to the development of small and medium-sized enterprises (Radulescu et al., 2021). Thus, in terms of economic development, they can become a key driver (Tolstoy et al., 2021).

The decision to locate or to continue the activities of a subsidiary of a foreign company depends on the degree of income taxation in the host country. Also, the level at which the company invests in that subsidiary depends on these taxes (Farah et al., 2021). At the same time, migration influences the labor force in a country (Negescu Oancea, et al., 2020). This phenomenon leads to both significant demographic changes and changes in the workforce (Hajro et al., 2021). The increasing participation of companies in international markets is due to the economic transition (Jianu et al., 2019). Regardless of their size, as well as the year of establishment, companies participate in an internationalization process (Ipsmiller \& Dikova, 2021).

Business process management allows companies' management, through different methods and techniques, applying various tools, to design processes, to manage models and new technologies (Reijers, 2021).

Digitization has allowed automation and control systems to be used in production and transportation processes in various industries (Boyes et al., 2018).

Industrial competitiveness can be achieved with the help of people who have the skills needed to apply artificial intelligence and new technologies (Burlacu et al., 2019). From this point of view, the measures that allow participation in education and training programs are important (Androniceanu \& Burlacu, 2017). Changes in the labor market require the retraining or upgrading of staff in companies (Sarbu et al., 2021).

Acquiring those skills and that level of education that meets the demands of the labor market is a goal of any employee (Lindemann \& Gangl, 2019).

However, it is considered that worldwide there has been a decrease in qualified educational standards through the rapid increase in the level of education (Sari et al., 2016)

For many industries, funding in education has led to the modernization of employee skills (Pasławski et al., 2016).

Also, in order to ensure a competitive industry, new sustainable economic models must take into account the need to invest in digitization, clean technologies, artificial intelligence, as well as in innovation and research. In production processes, the importance of improving industrial competitiveness increases. Research and innovation contribute to this aspect, but also to increase the efficiency of resources, respectively of primary and secondary raw materials.

Globally, the industrial sector consumes the most energy. The biggest challenge is to reduce energy consumption. This reduction is intended to take place without adversely 
affecting productivity and profits (Mawson \& Hughes, 2019). Access to raw materials and low-emission greenhouse gas services is a requirement of the new economic environment. Adapting to these changes allows the industry to remain competitive.

An improved interaction between the sectors of economies and educational institutions allows future graduates to acquire those skills that will help them in future jobs (Musaeva, 2015).

\section{Methodology of Research}

The article presents an analysis of employment in companies active in the Member States of the European Union. The evolution of the establishment of active enterprises according to their branches of activity is also addressed.

From the point of view of mobility, employment in foreign affiliates of domestic enterprises is another subdomain analyzed in the article. The article presents an analysis of the way in which expenditure is shared at the level of enterprises in the Member States of the European Union.

\section{Results and Discussions}

Depending on the existing data on the EUROSTAT website, the following table presents the comparative situation of the share of persons employed in foreign affiliates of domestic enterprises in the total number of persons employed (\%).

It is observed that in 2018, compared to 2010, the share of persons employed in foreign affiliates of domestic enterprises in the total number of persons employed increased in: Denmark (+14,86\%), France (+4,79\%), Belgium ( $+3,62 \%)$, Malta $(+3,38 \%)$, Sweden $(+2,77 \%)$, Lithuania $(+2,69 \%)$, Portugal $(+2,30 \%)$, Croatia $(+2,30 \%)$. Also, in 2018 , the highest values were recorded in: Denmark $(39,92 \%)$, Ireland $(39,86 \%)$, Luxembourg $(39,21 \%)$, Sweden $(30,76 \%)$, France $(29,23 \%)$, Finland $(24,29 \%)$. The lowest values were in: Romania (0,13\%), Czech Republic (0,95\%), Slovakia (1,01\%), Poland (1,28\%), Hungary $(1,49 \%)$, Latvia $(1,71 \%)$, Greece $(1,78 \%)$.

Table 1: The comparative situation of the share of persons employed in foreign affiliates of domestic enterprises out of the total persons employed (\%), 2010-2018

\begin{tabular}{|l|c|c|c|c|c|c|c|c|c|}
\hline GEO/TIME & 2010 & 2011 & 2012 & 2013 & 2014 & 2015 & 2016 & 2017 & 2018 \\
\hline Belgium & 7,32 & 9,3 & 9,3 & 13,03 & 12,68 & 11,67 & 11,21 & 10,62 & 10,94 \\
\hline Czechia & 0,92 & 0,83 & 0,83 & 0,93 & 0,99 & 0,91 & 0,82 & 0,93 & 0,95 \\
\hline Denmark & 25,06 & 39,99 & 39,99 & 40,78 & 40,87 & 40,59 & 40,35 & $:$ & 39,92 \\
\hline Germany & 15,82 & 15,74 & 15,74 & 16,28 & 16,02 & 16,55 & 16,41 & 16,6 & 16,43 \\
\hline Ireland & 39,93 & 38,81 & 38,81 & $:$ & 37,54 & 37,31 & 40,28 & 40,07 & 39,86 \\
\hline Greece & 3,34 & 3,72 & 3,72 & 3,95 & 3,64 & 3,58 & 2,46 & 2,27 & 1,78 \\
\hline Spain & 6,81 & 7,89 & 7,89 & 6,94 & 7,49 & 7,48 & 7,74 & 7,8 & 7,71 \\
\hline France & 24,44 & 25,72 & 25,72 & 26,89 & 27,14 & 28,18 & 28,15 & 28,69 & 29,23 \\
\hline Croatia & 1,88 & 2,18 & 2,18 & 2,32 & 4,12 & 4,24 & 4,22 & 3,25 & 4,18 \\
\hline Italy & 9,49 & 10,23 & 10,23 & 10,91 & 11,33 & 11,25 & 10,56 & $:$ & $:$ \\
\hline Cyprus & 9,78 & 8,56 & 8,56 & 8,16 & 7,2 & 6,8 & 5,86 & 5,09 & 4,47 \\
\hline Latvia & 1,15 & 1,26 & 1,26 & 1,34 & 1,38 & 1,47 & 1,34 & 1,58 & 1,71 \\
\hline
\end{tabular}




\begin{tabular}{|l|c|c|c|c|c|c|c|c|c|}
\hline GEO/TIME & 2010 & 2011 & 2012 & 2013 & 2014 & 2015 & 2016 & 2017 & 2018 \\
\hline Lithuania & 3,08 & 3,16 & 3,16 & 3,71 & 4,03 & 4,49 & 4,65 & 4,84 & 5,77 \\
\hline Luxembourg & 52,4 & 45,36 & 45,36 & 46,67 & 44,45 & 43,47 & 41,62 & 41,52 & 39,21 \\
\hline Hungary & 1,56 & 1,75 & 1,75 & 1,92 & 1,76 & 1,65 & 1,47 & 1,56 & 1,49 \\
\hline Malta & 3,53 & 4,05 & 4,05 & 5,24 & 5,05 & 5,79 & 7,05 & 7,59 & 6,91 \\
\hline Austria & 18,01 & 17,94 & 17,94 & 17,33 & 17,23 & 17,1 & 16,84 & 17,53 & 18 \\
\hline Poland & 0,96 & 0,97 & 0,97 & 0,93 & 1,07 & 1,08 & 1,18 & 1,17 & 1,28 \\
\hline Portugal & 3,59 & 3,33 & 3,33 & 5,21 & 5,6 & 6,1 & 5,91 & 5,74 & 5,89 \\
\hline Romania & 0,04 & 0,02 & 0,02 & 0,07 & 0,06 & 0,06 & 0,11 & 0,11 & 0,13 \\
\hline Slovenia & 8 & 8,44 & 8,44 & 7,94 & 5,98 & 5,51 & 5,51 & 5,41 & 4,87 \\
\hline Slovakia & 0,98 & 1,01 & 1,01 & 1,12 & 1,26 & 1,16 & 0,93 & 0,98 & 1,01 \\
\hline Finland & 25,13 & 25,66 & 25,66 & 23,77 & 22,55 & 22,67 & 25,03 & 24,01 & 24,29 \\
\hline Sweden & 27,99 & 28,41 & 28,41 & 29,13 & 30,79 & 30,99 & 30,67 & 30,54 & 30,76 \\
\hline
\end{tabular}

Source: processing according to data published by EUROSTAT, 2021

The evolution of this indicator, for the European Union, is shown in the following figure:

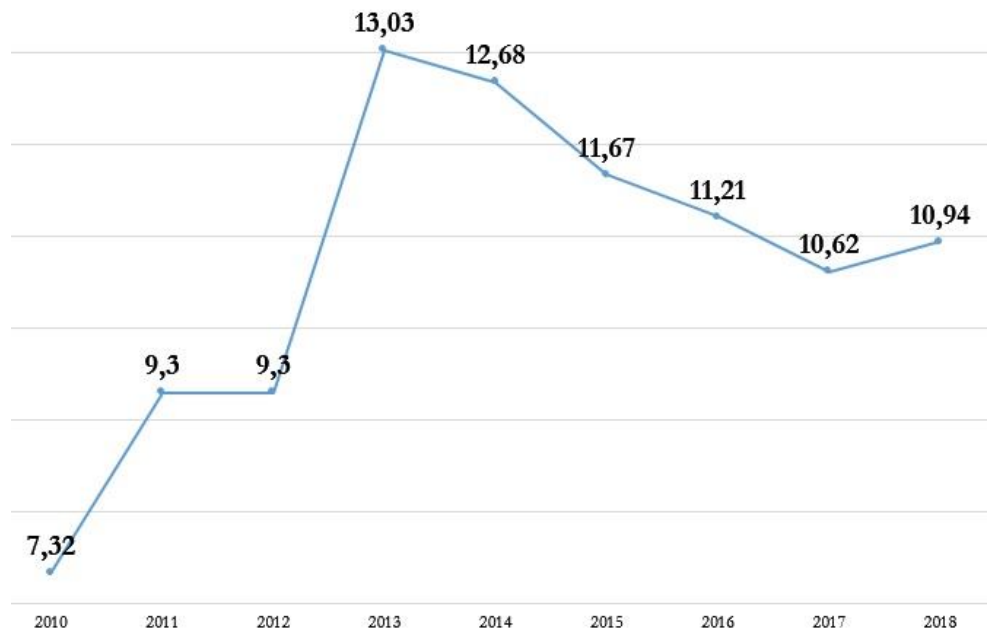

Figure 1: The evolution of the share of persons employed in foreign affiliates of domestic enterprises from the total persons employed, 2010-2018

Source: processing according to data published by EUROSTAT, 2021

From the previous figure, we notice that the values of the share of persons employed in foreign affiliates of domestic enterprises in the total number of persons employed had an ascending evolution for the period 2010-2013 (from 7,32\% to 13,03\%). In the period 20132017, the values had a downward evolution (from 13,03\% to 10,62\%). It is also observed that for the period 2017-2018 the trend is increasing.

From the data processing on the EUROSTAT website, the following table shows expenditures of enterprises by area of expenditure, for the total economic activities, for the countries with the highest values (thousand euro). 
Table 2: Comparative situation of expenditures of enterprises by area of expenditure, for total economic activities, 2018, (thousand euro)

\begin{tabular}{|l|c|c|c|c|c|}
\hline Expenditures & Germany & Spain & France & Italy & Poland \\
\hline $\begin{array}{l}\text { Expenditure on innovation (including } \\
\text { R\&D) }\end{array}$ & 157904304 & 18434192 & 65601487 & 45510295 & 8561178 \\
\hline Expenditure on R\&D activities & 90942308 & 10109703 & 52127546 & 22289067 & 3801949 \\
\hline Expenditure on R\&D performed in-house & 76111948 & 7930272 & 37207982 & 16807357 & 3391354 \\
\hline Expenditure on R\&D contracted out & 14830360 & 2179433 & 14316246 & 5481709 & 434617 \\
\hline $\begin{array}{l}\text { Expenditure on innovation (excluding } \\
\text { R\&D) }\end{array}$ & 66961996 & 8324489 & 13473943 & 23221230 & 3988916 \\
\hline Own personnel working on innovation & 11513534 & 950788 & 4599602 & 6496053 & 333508 \\
\hline $\begin{array}{l}\text { Capital goods for innovation (acquisition } \\
\text { of machinery, equipment, software, } \\
\text { intellectual property rights (IPRs), } \\
\text { buildings, etc.) }\end{array}$ & 38191490 & 5587624 & 2487506 & 6991875 & 2871480 \\
\hline $\begin{array}{l}\text { Services, materials, supplies purchased for } \\
\text { innovation }\end{array}$ & 16984018 & 1786076 & 4575407 & 9733300 & 424908 \\
\hline $\begin{array}{l}\text { Acquisition of machinery, equipment, } \\
\text { buildings and other tangible assets }\end{array}$ & 126221160 & 51585202 & 920932984 & $:$ & 97866358 \\
\hline $\begin{array}{l}\text { Software development, database work and } \\
\text { data analysis (include in-house costs and } \\
\text { purchased services) }\end{array}$ & 36136209 & 7100875 & 93140353 & $:$ & 3699029 \\
\hline $\begin{array}{l}\text { Registering, filing and monitoring own } \\
\text { Intellectual Property Rights (IPRs) and } \\
\text { purchasing or licensing IPRs from others }\end{array}$ & 3674694 & 776501 & 4858008 & $:$ & 540808 \\
\hline $\begin{array}{l}\text { Marketing, brand building, advertising } \\
\text { (include in-house costs and purchased } \\
\text { services) }\end{array}$ & 48324841 & 10907751 & 68727427 & $:$ & 5247076 \\
\hline $\begin{array}{l}\text { Training own staff (include all in-house } \\
\text { costs including wages and salaries of staff } \\
\text { while being trained, and costs of } \\
\text { purchased services from others) }\end{array}$ & 6749462 & 1107602 & 44891996 & $:$ & 2680906 \\
\hline $\begin{array}{l}\text { Product design (include in-house costs } \\
\text { and purchased services) }\end{array}$ & 3790501 & 4919652 & 20242980 & $:$ & 2099974 \\
\hline
\end{tabular}

Source: processing according to data published by EUROSTAT, 2021

Thus, from the data presented, for the field of expenditure on innovation (including R\&D), total economic activities, the largest amounts were spent by Italy $(33.33 \%$ of the total amounts spent), Germany (22,61\% of the total amounts spent) and Spain (14\% of total amounts spent). Another field with high shares is: acquisition of machinery, equipment, buildings and other tangible assets. For this area, Poland had the highest expenditures $(71,99 \%$ of the total amounts spent), followed by France $(68,36 \%$ of the total amounts spent), Spain (39,17\% of the total amounts spent) and Germany $(18,07 \%$ of the total amounts spent).

Germany also had high expenditures for: expenditure on R\&D activities $(13,02 \%$ of total sums spent), expenditure on R\&D performed in-house (10,90\% of total sums spent) and expenditure on innovation (excluding R\&D) (9,59\% of the total amounts spent). Spain 
also spent more on: Marketing, brand building, advertising (includes in-house costs and purchased services) (8,28\% of total amounts spent), expenditure on R\&D activities $(7,68 \%$ of total amounts spent), expenditure on innovation (excluding R\&D) $(6,32 \%$ of total amounts spent).

Another indicator analyzed is newly born enterprises. Thus, the following figure shows the comparative situation of the number of newly born enterprises in 2015 and which are still active in 2018.

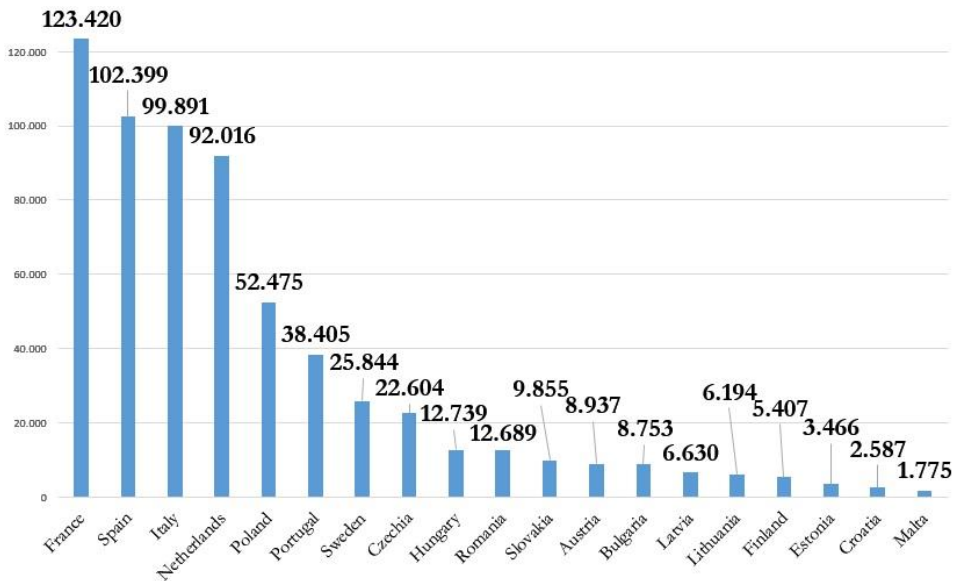

Figure 2: The comparative situation of the number of newly born enterprises in 2015 and which are still active in 2018

Source: processing according to data published by EUROSTAT, 2021

From the previous figure, it can be seen that most newly born enterprises in 2015 and are still active in 2018 are found in France (123420 enterprises), followed by Spain (102399 enterprises), Italy (99891 enterprises), Netherlands (92016 enterprises). ) and Poland (52475 enterprises). The fewest are in Malta (1775 enterprises), Croatia (2587 enterprises), Estonia (3466 enterprises), Finland (5407 enterprises).

Given the situation analyzed above, the following table presents the comparative situation of the number of employees in newly born enterprises in 2015 and which are still active in 2018.

Table 3: Comparative situation of the number of employees in newly born enterprises in 2015 and which are still active in 2018

\begin{tabular}{|c|c|c|c|c|c|c|c|c|c|c|}
\hline \multirow[t]{2}{*}{ Countries } & \multicolumn{2}{|c|}{$\begin{array}{c}\text { Industry } \\
\text { (except } \\
\text { construction) }\end{array}$} & \multicolumn{2}{|c|}{ Construction } & \multicolumn{2}{|c|}{$\begin{array}{l}\text { Wholesale and } \\
\text { retail trade; repair } \\
\text { of motor vehicles } \\
\text { and motorcycles }\end{array}$} & \multicolumn{2}{|c|}{$\begin{array}{l}\text { Transportation } \\
\text { and storage }\end{array}$} & \multicolumn{2}{|c|}{$\begin{array}{l}\text { Accommodation } \\
\text { and food service } \\
\text { activities }\end{array}$} \\
\hline & 2008 & 2018 & 2008 & 2018 & 2008 & 2018 & 2008 & 2018 & 2008 & 2018 \\
\hline Bulgaria & 3815 & 2906 & 6779 & 2523 & 12299 & 6500 & 2132 & 1168 & 1992 & 2498 \\
\hline Czechia & $:$ & 6308 & : & 3610 & $:$ & 8729 & : & 1585 & : & 2368 \\
\hline Denmark & 406 & : & 1252 & $:$ & 1468 & : & 523 & : & 1003 & : \\
\hline Estonia & 1082 & 816 & 1452 & 966 & 3767 & 1322 & 298 & 394 & 379 & 485 \\
\hline
\end{tabular}




\begin{tabular}{|c|c|c|c|c|c|c|c|c|c|c|}
\hline \multirow[t]{2}{*}{ Countries } & \multicolumn{2}{|c|}{$\begin{array}{c}\text { Industry } \\
\text { (except } \\
\text { construction) }\end{array}$} & \multicolumn{2}{|c|}{ Construction } & \multicolumn{2}{|c|}{$\begin{array}{l}\text { Wholesale and } \\
\text { retail trade; repair } \\
\text { of motor vehicles } \\
\text { and motorcycles }\end{array}$} & \multicolumn{2}{|c|}{$\begin{array}{l}\text { Transportation } \\
\text { and storage }\end{array}$} & \multicolumn{2}{|c|}{$\begin{array}{c}\text { Accommodation } \\
\text { and food service } \\
\text { activities }\end{array}$} \\
\hline & 2008 & 2018 & 2008 & 2018 & 2008 & 2018 & 2008 & 2018 & 2008 & 2018 \\
\hline Spain & $:$ & $:$ & 82356 & 33330 & 68154 & 61255 & 19313 & 14318 & : & 39772 \\
\hline France & $:$ & 14035 & $:$ & 28675 & $:$ & 38751 & : & 17084 & : & 21054 \\
\hline Croatia & $:$ & 1109 & $:$ & 733 & $:$ & 2800 & $:$ & 117 & $:$ & 910 \\
\hline Italy & 31254 & 29578 & 49734 & 25511 & 47127 & 48344 & 18842 & 24470 & 21004 & 34660 \\
\hline Latvia & $:$ & 1257 & $:$ & 1860 & $:$ & 3498 & $:$ & 930 & $:$ & 1660 \\
\hline Lithuania & $:$ & 1148 & $:$ & 1459 & $:$ & 2812 & $:$ & 1059 & $:$ & 921 \\
\hline Hungary & 2741 & 2364 & 1849 & 2453 & 7007 & 7935 & 1228 & 1419 & 1142 & 2241 \\
\hline Malta & : & 303 & $:$ & 307 & : & 965 & : & 126 & : & 486 \\
\hline Netherlands & 2471 & 5548 & 6039 & 10320 & 9646 & 21187 & 1718 & 3913 & 3292 & 15181 \\
\hline Austria & 1232 & 913 & 2030 & 2565 & 3144 & 4733 & 1229 & : & 2052 & 3566 \\
\hline Poland & 26717 & 16583 & 14761 & 12414 & 36213 & 25615 & 7068 & 7926 & 5674 & 5882 \\
\hline Portugal & $:$ & 5680 & $:$ & 6368 & $:$ & 12025 & $:$ & 1541 & $:$ & 11563 \\
\hline Romania & 9683 & 3511 & 9194 & 4495 & 27930 & 10167 & 3056 & 3131 & 1572 & 3211 \\
\hline Slovakia & 1785 & 2986 & 828 & 1338 & 4330 & 5350 & 1441 & 1103 & 989 & 619 \\
\hline Finland & 372 & 483 & 1264 & 1956 & 1098 & 1286 & 517 & 532 & 523 & 1023 \\
\hline Sweden & : & 1300 & : & 5954 & : & 5287 & : & 1452 & : & 3891 \\
\hline
\end{tabular}

Source: processing according to data published by EUROSTAT, 2021

It is noted that for the Netherlands, for all sectors analyzed, the number of employees increased in 2018 compared to 2008. The highest increase is recorded for wholesale and retail trade; repair of motor vehicles and motorcycles (+11541 persons) and for accommodation and food service activities (+11889 persons). Also, among these sectors, in 2018 compared to 2008, the most significant decreases are registered for the construction sector. In Spain, for this sector, the number of employees decreased by 49026 persons, and in Italy the decrease was by 24223 persons. At the same time, significant declines for several countries were recorded for the wholesale and retail trade sector; repair of motor vehicles and motorcycles. Thus, we have: Romania (-6563 persons), Poland (10598 persons), Spain (-6899 persons), Bulgaria (-5799 persons), Estonia (-2445 persons). From the point of view of the degree of development of enterprises, the following table presents the comparative situation of high-growth enterprises measured in employment (growth of 10\% or more), for the period 2008-2018.

Table 4: Comparative situation of high-growth enterprises measured in employment (growth of $10 \%$ or more), 2008-2018

\begin{tabular}{|c|c|c|c|c|c|c|c|c|c|c|}
\hline \multirow[t]{2}{*}{ Countries } & \multicolumn{2}{|c|}{$\begin{array}{c}\text { Industry } \\
\text { (except } \\
\text { construction) }\end{array}$} & \multicolumn{2}{|c|}{ Construction } & \multicolumn{2}{|c|}{$\begin{array}{l}\text { Wholesale and } \\
\text { retail trade; repair } \\
\text { of motor vehicles } \\
\text { and motorcycles }\end{array}$} & \multicolumn{2}{|c|}{$\begin{array}{c}\text { Transportation } \\
\text { and storage }\end{array}$} & \multicolumn{2}{|c|}{$\begin{array}{c}\text { Accommodation } \\
\text { and food service } \\
\text { activities }\end{array}$} \\
\hline & 2008 & 2018 & 2008 & 2018 & 2008 & 2018 & 2008 & 2018 & 2008 & 2018 \\
\hline Bulgaria & 228 & 150 & 229 & 114 & 447 & 305 & 69 & 73 & 79 & 68 \\
\hline Czechia & $:$ & 322 & $:$ & 148 & $:$ & 427 & : & 171 & : & 164 \\
\hline Denmark & 33 & : & 67 & : & 115 & $:$ & 43 & : & 17 & : \\
\hline
\end{tabular}




\begin{tabular}{|c|c|c|c|c|c|c|c|c|c|c|}
\hline \multirow[t]{2}{*}{ Countries } & \multicolumn{2}{|c|}{$\begin{array}{c}\text { Industry } \\
\text { (except } \\
\text { construction) }\end{array}$} & \multicolumn{2}{|c|}{ Construction } & \multicolumn{2}{|c|}{$\begin{array}{l}\text { Wholesale and } \\
\text { retail trade; repair } \\
\text { of motor vehicles } \\
\text { and motorcycles }\end{array}$} & \multicolumn{2}{|c|}{$\begin{array}{l}\text { Transportation } \\
\text { and storage }\end{array}$} & \multicolumn{2}{|c|}{$\begin{array}{c}\text { Accommodation } \\
\text { and food service } \\
\text { activities }\end{array}$} \\
\hline & 2008 & 2018 & 2008 & 2018 & 2008 & 2018 & 2008 & 2018 & 2008 & 2018 \\
\hline Estonia & 104 & 100 & 84 & 66 & 164 & 87 & 42 & 40 & 26 & 39 \\
\hline Spain & : & $:$ & $:$ & 2.127 & $:$ & : & $:$ & $:$ & : & $:$ \\
\hline France & $:$ & 917 & $:$ & 1.015 & $:$ & 1.379 & $:$ & 565 & $:$ & 746 \\
\hline Croatia & : & 83 & $:$ & 58 & $:$ & 152 & $:$ & 21 & $:$ & 28 \\
\hline Italy & 2.459 & 2.520 & 1.302 & 974 & 1.526 & 1.782 & 638 & 896 & 615 & 1.140 \\
\hline Latvia & $:$ & 71 & $:$ & 95 & $:$ & 146 & $:$ & 73 & $:$ & 30 \\
\hline Lithuania & $:$ & 78 & $:$ & 72 & $:$ & 119 & $:$ & 126 & $:$ & 31 \\
\hline Hungary & 173 & 185 & 144 & 134 & 370 & 330 & 88 & 80 & 93 & 136 \\
\hline Malta & $:$ & 41 & $:$ & 16 & $:$ & 89 & $:$ & 30 & $:$ & 40 \\
\hline Netherlands & 691 & 899 & 370 & 542 & 1.356 & 1.860 & 419 & 473 & 599 & 1.054 \\
\hline Austria & 111 & 101 & 131 & 166 & 222 & 193 & 82 & 58 & 120 & 183 \\
\hline Poland & $:$ & 966 & $:$ & $:$ & $:$ & 1.075 & $:$ & 349 & $:$ & $:$ \\
\hline Portugal & 595 & 652 & 499 & 382 & 594 & 654 & 176 & 193 & 279 & 442 \\
\hline Romania & 124 & 59 & 135 & 28 & 352 & 126 & 42 & 26 & 29 & 26 \\
\hline Slovakia & 90 & 59 & 34 & 26 & 183 & 136 & 50 & 61 & 24 & 39 \\
\hline Finland & 123 & 66 & 111 & 175 & 254 & 136 & 73 & 65 & 42 & 61 \\
\hline Sweden & $:$ & 239 & $:$ & 427 & $:$ & 461 & $:$ & 205 & $:$ & 189 \\
\hline
\end{tabular}

Source: processing according to data published by EUROSTAT, 2021

Depending on the data available, it is observed that for certain sectors of activity, respectively certain countries, the values increase or decrease. These differences can be explained by the degree to which these sectors are developing and allow the opening of new jobs within companies. For example, the Netherlands had increases for all sectors analyzed. For industry (from 691 enterprises in 2008 to 899 enterprises in 2018), for construction (from 370 enterprises in 2008 to 542 enterprises in 2018), for wholesale and retail trade; repair of motor vehicles and motorcycles (from 1356 enterprises in 2008 to 1860 enterprises in 2018), for transportation and storage (from 419 enterprises in 2008 to 473 enterprises in 2018), for accommodation and food service activities (from to 599 enterprises in 2008 to 1054 enterprises in 2018). Italy also had increases for several sectors, such as: accommodation and food service activities ( +525 enterprises), transportation and storage (+258 enterprises), wholesale and retail trade; repair of motor vehicles and motorcycles ( +256 enterprises).

Regarding the decreases, from the presented data, only Romania had decreases in values for all the analyzed sectors. The most significant decreases were in: wholesale and retail trade; repair of motor vehicles and motorcycles (-226 enterprises) and construction (-117 enterprises).

\section{Conclusions}

It is believed that industry and related services can stimulate sustainable growth, employment and economic development in Europe (EC, 2021). 
It is observed that in 2018, compared to 2010, the share of persons employed in foreign affiliates of domestic enterprises in the total number of persons employed increased in all European Union countries.

Expenditure on innovation, followed by the acquisition of machinery, equipment, buildings and other tangible assets, are the areas for which expenditures had the highest values. Also, at least one thousand newly born enterprises in 2015 are still active in 2018 for each country in the European Union.

The number of jobs will decrease mainly in those sectors that are closely related to technological processes (Angheluță et al., 2020). Thus, current employment patterns will change (CEDEFOP, 2018).

\section{References}

Androniceanu, A., \& Burlacu, S. (2017). Integration of Educational Technologies in Universities and Students'perception Thereof. In The International Scientific Conference eLearning and Software for Education(Vol. 2, p. 26). " Carol I" National Defence University.

Androniceanu, A., Burlacu, S., Drăgulănescu, I. V., \& Nicolae, E. E. (2017, May). New trends of businesses digitalization in Romania and the behaviour young consumers. In BASIQ International Conference: New Trends in Sustainable Business and Consumption, Graz (Vol. 31, pp. 27-35).

Angheluță, P.S., Negescu Oancea, M.D., Diaconu, A., Dima, C. (2020). Dynamics of Establishment of the Enterprises and the Entrepreneurship in Romania, European Journal of Sustainable Development, 9, 3, 116-126.

Angheluta, S. P., Burlacu, S., Diaconu, A., \& Curea, C. S. (2019). The Energy from Renewable Sources in the European Union: Achieving the Goals. European Journal of Sustainable Development, 8(5), 57.

Boyes, H., Hallaq, B., Cunningham, J., Watson, T. (2018). The industrial internet of things (IIoT): An analysis framework, Computers in Industry, 101, 1-12.

Bran, F.., Alpopi, C., \& Burlacu, S. (2018). Territorial Development-Disparities between the Developed and the least Developed Areas of Romania. LUMEN Proceedings, 6(1), 146-155.

Burlacu, S., Profiroiu, A., \& Vasilache, P. C. (2019). Impact of Demography on the Public Finance of the European Union. Calitatea, 20(S2), 136-138.

Cedefop (European Centre for the Development of Vocational Training) (2018). Can work and technology go hand-in-hand? https://skillspanorama.cedefop.europa.eu/en/blog/can-work-and-technologygo-hand-hand. Accessed 16/05/2021.

Costache, G., Marinas, C. V., Igret, R., \& Burlacu, S. (2015). Internship in the HR Department-Organizational and Individual Perspectives. In Proceedings of the International Management Conference (Vol. 9, No. 1, pp. 359-370). Bucharest, Romania.

Curry, M. (2019). The Great Recession and shifting patterns of college effects for young men, Research in Social Stratification and Mobility, 59, 34-45.

EC (European Commission) (2020). A new Circular Economy Action Plan. For a cleaner and more competitive Europe. https://eur-lex.europa.eu/legal-content/EN/TXT/?qid=1583933814386 \&uri=COM:2020:98:FIN. Accessed 14/05/2021.

EC (European Commission) (2021). Updating the 2020 New Industrial Strategy: Building a stronger Single Market for Europe's recovery. https://ec.europa.eu/info/sites/default/files/communicationindustrial-strategy-update-2020_en.pdf. Accessed 15/05/2021.

Eurostat (2021). Database, https://ec.europa.eu/eurostat/web/main.

Farah, B., Elias, R., Chakravarty, D., Beamish, P. (2021). Host country corporate income tax rate and foreign subsidiary survival, Journal of World Business, 56, 101186.

Grodzicki , M.J. \& Skrzypek, J. (2020). Cost-competitiveness and structural change in value chains - verticallyintegrated analysis of the European automotive sector, Structural Change and Economic Dynamics, 55, 276-287.

Hajro, A., Caprar, D.V., Zikic, J., Stahl, G.K. (2021). Global migrants: Understanding the implications for international business and management, Journal of World Business, 56, 101192. 
Ionita, F., Ursacescu, M., \& Burlacu, S. (2009). Public Services as Poles of Regional Competitiveness in Sustainable Development. Revista de Management Comparat International/Review of International Comparative Management, 10(3), 552-565.

Ionita, F.; Burlacu, S. \& Gaidargi, A.(2009). Modern Approaches of the Management of Alternative Trade Systems, Revista de Management Comparat International/ Review of International Comparative Management,51, 473-480

Ipsmiller, E. \& Dikova, D. (2021). Internationalization from Central and Eastern Europe: A systematic literature review, Journal of International Management, 27, 100862.

Jianu, I., Dobre, I., Bodislav, D. A., Radulescu, C. V., \& Burlacu, S. (2019). The Implications of Institutional Specificities on the Income Inequalities Drivers in European Union. Economic Computation and Economic Cybernetics Studies and Research, 53(2), 59-76.

Lindemann, K., Gangl, M. (2019). The intergenerational effects of unemployment: How parental unemployment affects educational transitions in Germany, Research in Social Stratification and Mobility, 62, 100410.

Mawson, V.J., Hughes, B.R. (2019). The development of modelling tools to improve energy efficiency in manufacturing processes and systems, Journal of Manufacturing Systems, 51, 95-105.

Musaeva, K. (2015). Research Organizations and Business: Interaction Barriers in the Context of Innovative Development, Procedia - Social and Behavioral Sciences, 214, 201 - 211.

Negescu, M D; Burlacu, S; Mitriţă, M; Buzoianu, O C A. Managerial Analysis of Factoring at the International Level Challenges of the Contemporary Society. Proceedings; Cluj-Napoca Vol. 13, Iss. 1, : 99-102. ClujNapoca: Babes Bolyai University. (2020)

Pasławski, J., Nowotarski, P., Milwicz, R., Dubas, S. (2016). Improving Education of Managers in Construction Sector with the Use of EU Funds, Procedia Engineering, 161, 1043 - 1048.

Profiroiu, C. M., Bodislav, D. A., Burlacu, S., \& Rădulescu, C. V. (2020). Challenges of Sustainable Urban Development in the Context of Population Growth. European Journal of Sustainable Development, 9(3), 51-51.

Rădulescu, C. V., Bran, F., Burlacu, S., Dobrea, C. R., \& Diaconu, S. (2020, December). Challenges Regarding Food Resources in the Context of Globalization and Population Growth. In Proceedings of the International Conference on Economics and Social Sciences (pp. 1041-1052). Sciendo.

Radulescu, C.V.; Ladaru, G.-R.; Burlacu, S.; Constantin, F.; Ioanăș, C.; Petre, I.L. (2021) Impact of the COVID-19 Pandemic on the Romanian Labor Market. Sustainability 2021, 13, 271. https://doi.org/10.3390/su13010271

Reijers, H.A. (2021). Business Process Management: The evolution of a discipline, Computers in Industry, 126, 103404.

Sarbu, R., Alpopi, C., Burlacu, S., \& Diaconu, S. (2021). Sustainable urban development in the context of globalization and the health crisis caused by the covid-19 pandemic. Les Ulis: EDP Sciences. doi:http://dx.doi.org/10.1051/shsconf/20219201043

Sari, A., Firat, A., Karaduman, A. (2016). Quality Assurance Issues in Higher Education Sectors of Developing Countries; Case of Northern Cyprus, Procedia - Social and Behavioral Sciences, 229, 326 - 334.

Sullivan, S.E. \& Ariss, A.A. (2021). Making sense of different perspectives on career transitions: A review and agenda for future research, Human Resource Management Review, 31, 100727.

Tolstoy, D., Nordman, E.R., Hånell, S.M., Ozbek, N. (2021). The development of international e-commerce in retail SMEs: An effectuation perspective, Journal of World Business, 56, 101165. 